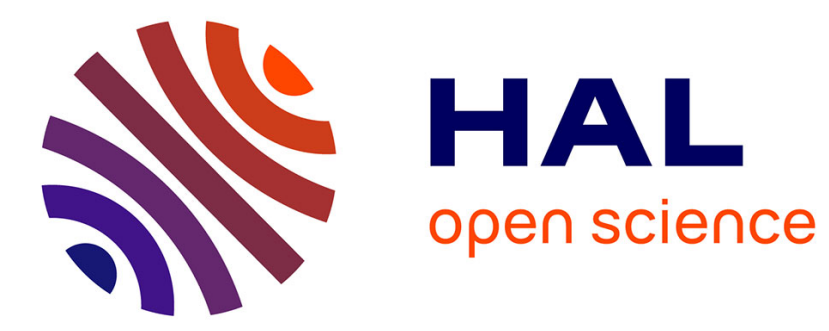

\title{
Cartes des Parcs Nationaux français
}

- [.]revue Forestière Française, Rédaction

\section{- To cite this version:}

- [.]revue Forestière Française, Rédaction. Cartes des Parcs Nationaux français. 1971, pp.247-248.

$10.4267 / 2042 / 20581$. hal-03534961

\section{HAL Id: hal-03534961 \\ https://hal.science/hal-03534961}

Submitted on 19 Jan 2022

HAL is a multi-disciplinary open access archive for the deposit and dissemination of scientific research documents, whether they are published or not. The documents may come from teaching and research institutions in France or abroad, or from public or private research centers.
L'archive ouverte pluridisciplinaire HAL, est destinée au dépôt et à la diffusion de documents scientifiques de niveau recherche, publiés ou non, émanant des établissements d'enseignement et de recherche français ou étrangers, des laboratoires publics ou privés. 


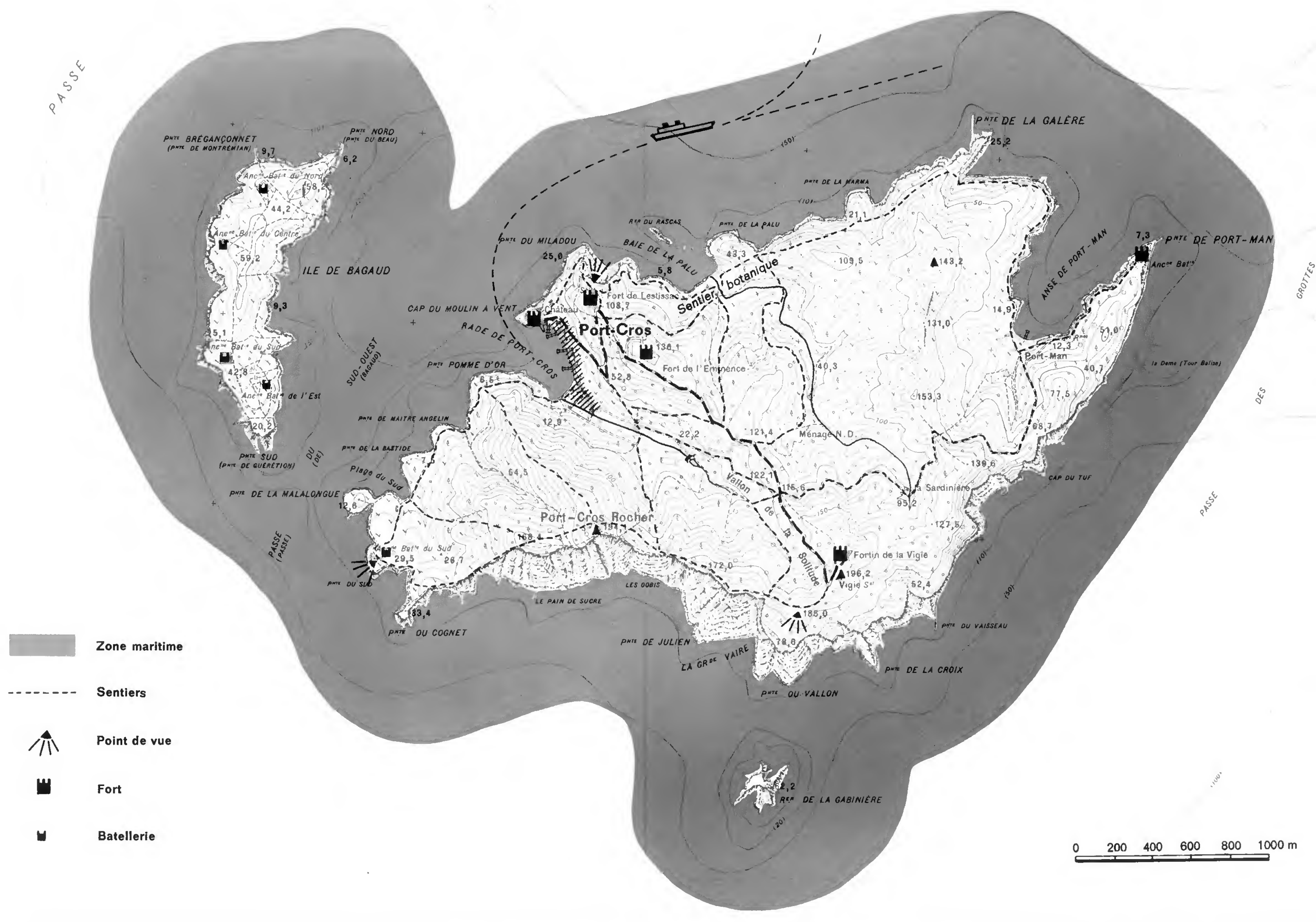


Parc national de Port-Cros 


\section{Le Parc national des Cévennes}




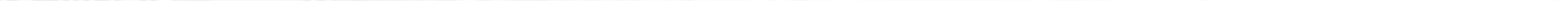


Parc national de la Vanoise 


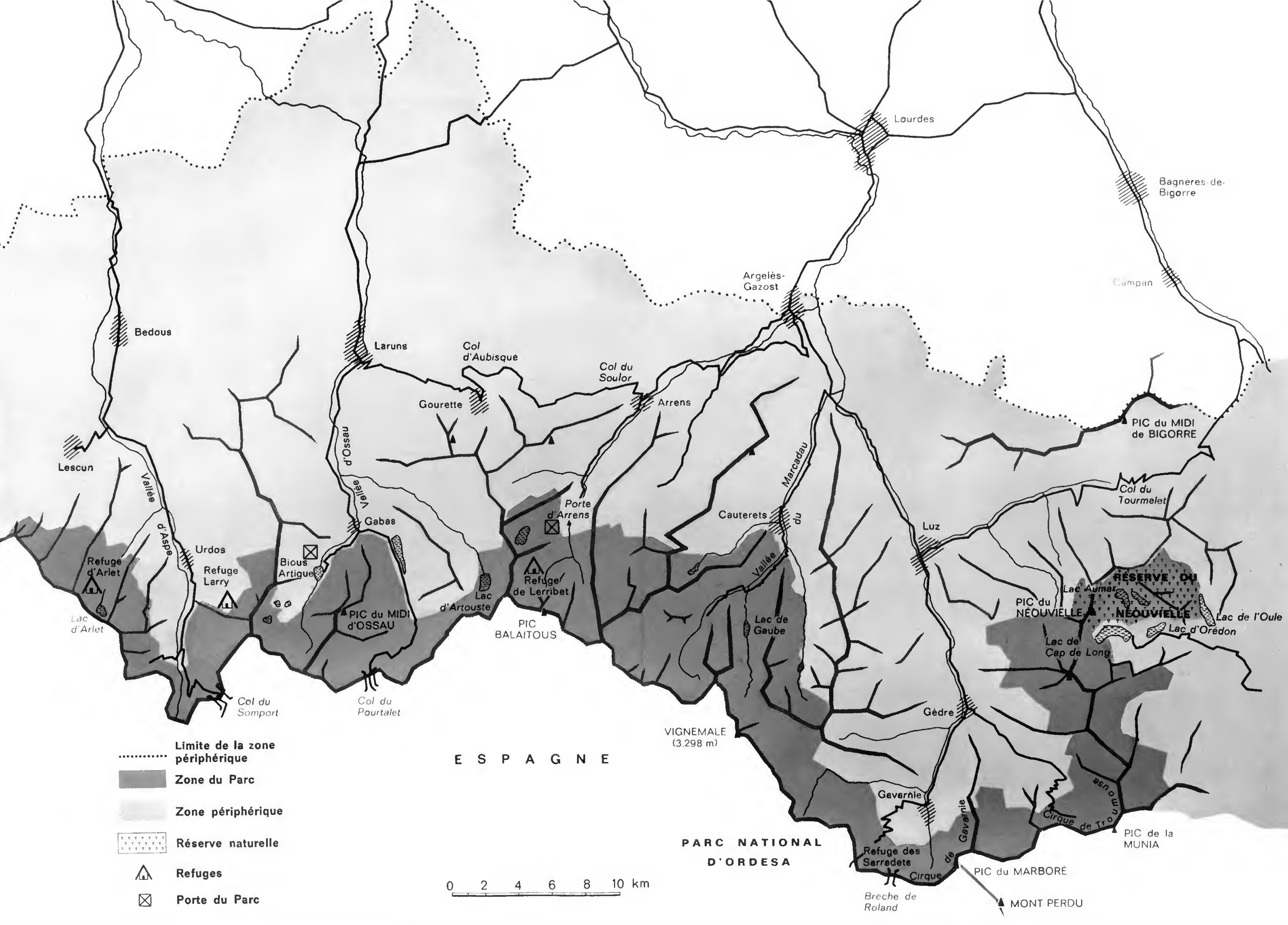




\section{Parc national des \\ Pyrénées-occidentales}

